\title{
Визначення специфічних ознак недиференційованої дисплазії сполучної тканини в паціентів на післяопераційну вентральну грижу з обгрунтуванням вибору оптимального способу операційного втручання і типу протеза
}

\begin{abstract}
Мета роботи: розпрацювати тактичні передумови та покращити результати хірургічного лікування хворих на післяопераційну вентральну грижу і попередити розвиток рецидиву на основі визначення клінічних ознак недиференційованої дисплазії сполучної тканини з подальшим вибором патогенетично обгрунтованого способу операційного втручання і вибору алотрансплантанта.

Матеріали і методи. Проаналізовано результати хірургічного лікування 106 пацієнтів, оперованих з приводу післяопераційної вентральної грижі з імплантацією легких та тяжких поліпропіленових сіток за умов наявної дисплазії сполучної тканини. Вивчали фенотипічні ознаки дисплазії сполучної тканини за міжнародна шкалою М. J. Glesby (1994). Для оцінки стану метаболізму вивчали вміст у сироватці крові оксипроліну. Нормативні величини біохімічних показників отримані при обстеженні 20 практично здорових осіб (контроль), які зіставлені за віком і статтю з обстеженими 106 хворими на післяопераційну вентральну грижу. Вміст кріоглобулінів сироватки крові визначали за методикою Н. А. Константинової та А. Ю. Кірсанова (1989). Для морфологічного дослідження на предмет визначення неспецифічної дисплазії сполучної тканини під час операційного втручання здійснювали забір фрагментів апоневрозу білої лінії живота поряд з грижею. У 5 хворих, яких повторно оперували з іншою патологією органів черевної порожнини, за їхньої згоди, керуючись нормами медичної біоетики, забирали фрагменти передньої черевної стінки з імплантованою тяжкою і легкою сіткою для подальшого морфологічного вивчення.

Результати досліджень та їх обговорення. Динаміка зростання колагенолітичної активності рівня глікозаміногліканів та вільного оксипроліну мали прямий кореляційний зв'язок із ступенем тяжкості неспецифічної дисплазії сполучної тканини. Так, при легкому ступені рівень сироваткового оксипроліну становив $(54,3 \pm 1,1)$ мкмоль/л, середньому ступені $(69,7 \pm 1,8)$ мкмоль/л та тяжкому ступені $(92,5 \pm 1,4)$ мкмоль/л, що практично в 8 разів перевищувало показники норми. Відповідна динаміка до зростання залежно від ступеня вираженості неспецифічної дисплазії сполучної тканини спостерігалась і при визначенні показників глікозамінглікану та кріоглобуліну. Так, у пацієнтів конторольної групи і у пацієнтів з ізольованою грижею показники глікозамінглікану практично не відрізнялись і становили $(39,25 \pm 0,9)$ мкмоль/л в сечі і відповідно $(41,3 \pm 1,1)$ мкмоль/л в сечі, проте в групі пацієнтів з середньою та важкою формами дисплазії сполучної тканини вони збільшувались у 2-2,5 раза $(101,9 \pm 1,3)$ мкмоль/л у сечі. Аналогічне зростання показників кріоглобуліну спостерігали в групах порівняння із зростанням тяжкості дисплазії сполучної тканини. Так, у нормі показники кріоглобуліну становили $(40,3 \pm 1,2)$ ум. од., при середньому ступені тяжкості НДСТ $(234,8 \pm 2,5)$ ум. од., а при тяжкому $(312,3 \pm 2,4)$ ум. од., що практично в шість разів перевищує норму. Морфологічні дослідження довели пріорититети при використанні легкої крупнопористої поліпропіленової сітки Омега-2, що проявлялось у відсутності периваскулярного набряку, формуванні пухкої грануляційної тканини навколо волокон, помірною кількість фібробластів, значною кількістю колагенових волокон, інфільтрованих лімфо- та гістіоцитами.
\end{abstract}

Ключові слова: післяопераційна вентральна грижа; рецидив; недиференційована дисплазія сполучної тканини (НДСТ); фенотипічні ознаки дисплазії; оксипролін; поліпропіленова сітка.

Постановка проблеми і аналіз останніх досліджень та публікацій. Одним із пізніх ускладнень лапаротомічних операцій є виникнення післяопераційних вентральних гриж (ПОВГ). Вирішення цього питання турбує хірургів протягом усього періоду існування абдомінальної хірургії $[1,7,11]$. Майже 15 \% усіх лапаротомій ускладнюється формуванням рубцевих гриж. Від післяопераційних вентральних гриж страждають близько 5-20 \% пацієнтів працездатного віку, що визначає проблему лікування таких хворих не тільки як медичну, але і як соціальну $[5,7]$. Зважаючи на досягнуті успіхи в хірургічному лікуванні післяопераційних вентральних гриж, кількість рецидивувань ПОВГ залишається досить високою. За да- ними The Ventral Hernia Working Group (VHWG), протягом 5 років спостережень після операцій 3 приводу ПОВГ частота повторних операцій після першого рецидиву складає $24 \%$, після другого рецидиву - $35 \%$, після третього рецидиву - $39 \%$ [8]. Однією з головних причин розвитку рецидиву грижі $є$ патогенетично необгрунтована операція без урахування наявності у хворого недиференційованої дисплазії сполучної тканини (НДСТ), що проявляється значним зниженням вмісту білка позаклітинного матриксу сполучної тканини - колагену, який визначає ії міцність [2, 3, 4, 6, 9, 10].

Мета роботи: покращити результати хірургічного лікування хворих на післяопераційну вентральну грижу та попередити розвиток рецидиву 
на основі визначення клінічних ознак недиференційованої дисплазії сполучної тканини з подальшим вибором патогенетично обгрунтованого способу операційного втручання і вибору алотрансплантанта.

Матеріали і методи. Робота базується на дослідженні 106 пацієнтів, оперованих у клініці хірургії ННІ ПО ТДМУ імені І. Я. Горбачевського на базі хірургічного відділення Тернопільської міської лікарні № 2 у період із 2011 до 2017 р. В усіх пацієнтів були наявні лише ПОВГ типу MW4R1 за класифікацією J. P. Chevrel, A. M. Rath (SWRclassification), 1999, з метою отримання статистично достовірних результатів. Усім пацієнтам виконано ретромускулярну пластику способом «Sub Lay» 3 імплантацією легкої сітки фірми «УKPTEXМЕД» - Омега-2 стандарт із діаметром поліпропіленової нитки 0,12 мм, товщиною 0,40 мм, пито-

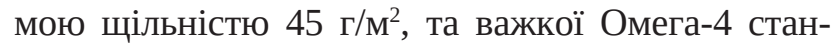
дарт із діаметром поліпропіленової нитки 0,12 мм,

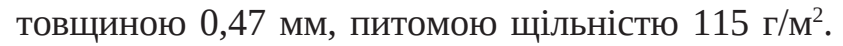
3 метою оцінки специфічних фенотипічних ознак дисплазії сполучної тканини використано міжнародну шкалу M. J. Glesby (1994). Брали до уваги, що виявлення 6 та більше стигм НДСТ може бути критичною кількістю ознак дисплазії сполучної тканини. Для оцінки стану метаболізму вивчали вміст у сироватці крові оксипроліну - основної амінокислоти, яка міститься в колагені. Нормативні величини біохімічних показників отримано при обстеженні 20 практично здорових осіб (контроль), які зіставлені за віком і статтю з обстеженими 106 хворими на післяопераційну вен- тральну грижу. Цей показник у нормі визначали в межах $(11,6 \pm 0,9)$ мкмоль/л. Дослідження метаболізму оксипроліну проводили колориметричним методом L. Bergman i R. Loxley у модифікації М. А. Осадчук і Т. П. Кузнєцової. Вміст кріоглобулінів сироватки крові визначали за методикою Н. А. Константинової та А. Ю. Кірсанова (1989), принцип якої полягає у встановленні різниці оптичної щільності розчину сироватки крові у веронал-мединаловому буфері $(\mathrm{pH}=8,6)$ при температури 4 та $37^{\circ} \mathrm{C}$. В контрольній групі цей показник був в межах норми і становив $\leq 50$ ум. од. Для морфологічного дослідження на предмет визначення неспецифічної дисплазії сполучної тканини під час операційного втручання здійснювали забір фрагментів апоневрозу білої лінії живота поряд 3 грижовим дефектом розміром 0,3 х 0,3 см. У 5 хворих, яких повторно оперували з іншою патологією органів черевної порожнини, за їхньої згоди, керуючись нормами медичної біоетики, забирали фрагменти передньої черевної стінки з імплантованою тяжкою і легкою сіткою для подальшого морфологічного вивчення. Вік хворих коливався від 49 до 72 років. Середній вік становив $(58,9 \pm 4,6)$ року. Контрольну групу склали 20 пацієнтів без необхідності проведення оперативного втручання та за відсутності фенотипових ознак неспецифічної дисплазії сполучної тканини (табл. 1).

Результати досліджень та їх обговорення. Розподіл обстежуваних хворих за віком, статевими ознаками та типом імплантованої сітки (тяжка дрібнопориста та легка крупнопориста) були розподілені так (табл. 1).

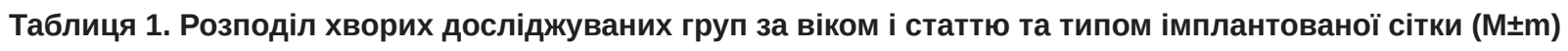

\begin{tabular}{||c|c|c|c|c||}
\hline \multirow{2}{*}{ Група } & \multicolumn{4}{|c||}{ Показник } \\
\cline { 2 - 5 } & $\begin{array}{c}\text { тип імплантованої сітки; } \\
\text { кількість хворих (n) }\end{array}$ & \multirow{2}{*}{ вік пацієнтів } & \multicolumn{2}{c||}{ стать хворих } \\
\cline { 2 - 5 } Основна & легка Омега-2, $\mathrm{n}=62$ & $59,6 \pm 1,8$ & $18(29,0 \%)$ & $44(71,0 \%)$ \\
\cline { 2 - 5 } & важка Омега-4, $\mathrm{n}=44$ & $58,2 \pm 1,4$ & $13(29,5 \%)$ & $31(70,5 \%)$ \\
\hline Усього & $\mathrm{n}=106$ & $58,9 \pm 4,6$ & $31(29,2 \%)$ & $75(70,8 \%)$ \\
\hline \multicolumn{3}{|c|}{ Вірогідність достовірна $\mathrm{p}<0,05$} \\
\hline
\end{tabular}

За характером операційного втручання, що призвело до утворення грижі, хворих було розподілено так (табл. 2).

Привертає увагу, що найчастіше причиною утворення післяопераційних вентральних гриж були операційні втручання з приводу первинних гриж білої лінії живота та пупкових гриж, проведені традиційними автопластичними способами
(33,8 \%), а також гінекологічні операційні втручання (25,0 \%). За наявною супутньою патологією хворих було розподілено так (табл. 3).

При оцінці фенотипічних ознак дисплазії сполучної тканини на основі карт Л. М. Фоміна та M. J. Glesby діагностовано плоскостопість у 14 (13,2 \%) хворих, підвищену розтяжність шкіри - у 16 (15,1 \%) хворих, варикозну хворобу нижніх 
Таблиця 2. Типи операційних втручань, які перенесли пацієнти основної групи

\begin{tabular}{||l|c|c||}
\hline \multicolumn{1}{|c|}{ Тип операційного втручання } & Абс. к-сть & Відсоток хворих \\
\hline Операційні втручання на шлунку та дванадцятипалій кишці & 7 & 7,6 \\
\hline Операційні втручання на органах гепатобіліарної системи & 14 & 15,2 \\
\hline Операційні втручання на товстій кишці & 6 & 6,5 \\
\hline Операційні втручання з приводу спайкової непрохідності & 11 & 11,9 \\
\hline Гінекологічні операційні втручання & 23 & 25,0 \\
\hline $\begin{array}{l}\text { Герніопластики з приводу первинних гриж білої лінії живота та пупкових } \\
\text { гриж автопластичними методиками }\end{array}$ & 31 & 33,8 \\
\hline Разом & 92 & 100 \\
\hline
\end{tabular}

Таблиця 3. Наявна супутня патологія в групі обстежених хворих

\begin{tabular}{|c|c|c|}
\hline Характер супутньої патології & Абс. к-сть & Відсоток хворих \\
\hline IXC, кардіосклероз, гіпертонічна хвороба & 63 & 68,5 \\
\hline Хронічна бронхопульмональна патологія & 19 & 20,7 \\
\hline Хронічні захворювання сечовидільної системи & 11 & 12,0 \\
\hline Варикозна хвороба нижніх кінцівок & 52 & 56,5 \\
\hline Морбідне ожиріння & 43 & 46,7 \\
\hline Ендокринопатії, в тому числі цукровий діабет & 14 & 15,2 \\
\hline
\end{tabular}

кінцівок - у 41 (38,7 \%) пацієнта, геморой - у 21 (19,8 \%), пролапс статевих органів - у 3 (2,8 \%), сколіоз, кіфоз, кіфосколіоз - у 4 (3,8 \%), гіпермобільність суглобів - 7 (6,6 \%). Усі ці фенотипічні ознаки були притаманні 31 (33,8 \%) пацієнту, якому проведено герніопластику 3 приводу первинних гриж білої лінії живота та пупкових гриж з використанням автопластичних методик. В них усіх підтверджено рецидив грижі.

Дослідження фенотипічних ознак неспецифічної дисплазії сполучної тканини в групі оперованих хворих показало, що у 23 (21,7 \%) з них були повністю відсутні ознаки неспецифічної дисплазії сполучної тканини (ізольована грижа), а рівень сироваткового оксипроліну склав $(12,5 \pm 0,8)$ мкмоль/л, що практично не відрізняється від показників контрольної групи $(11,6 \pm 0,9)$ мкмоль/л (табл. 4).

Динаміка зростання колагенолітичної активності рівня глікозаміногліканів та вільного оксипроліну мали прямий кореляційний зв'язок із сту- пенем тяжкості неспецифічної дисплазії сполучної тканини. Так, при легкому ступені рівень сироваткового оксипроліну становив $(54,3 \pm 1,1)$ мкмоль/л, середньому ступені $(69,7 \pm 1,8)$ мкмоль/л та тяжкому ступені $(92,5 \pm 1,4)$ мкмоль/л, що практично в 8 разів перевищувало показники норми. Відповідна динаміка до зростання залежно від ступеня вираженості неспецифічної дисплазії сполучної тканини спостерігалась і при визначенні показників глікозаміноглікану та кріоглобуліну. Так, у пацієнтів конторольної групи й у пацієнтів з ізольованою грижею показники глікозаміноглікану практично не відрізнялись і становили $(39,25 \pm 0,9)$ мкмоль/л в сечі і відповідно $(41,3 \pm 1,1)$ мкмоль/л в сечі, проте в групі пацієнтів з середньою та тяжкою формою дисплазії сполучної тканини вони збільшувались у $2-2,5$ раза $(101,9 \pm 1,3)$ мкмоль/л в сечі. Аналогічне зростання показників кріоглобуліну спостерігали в групах порівняння із зростанням тяжкості дисплазії сполучної тканини. Так, в нормі показники кріо-

Таблиця 4. Динаміка біохімічних показників стану сполучної тканини у хворих на пОВГ залежно від

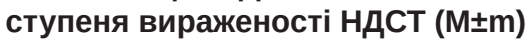

\begin{tabular}{||c|c|c|c|c||}
\hline \multirow{2}{*}{$\begin{array}{c}\text { Групи } \\
\text { обстеження }\end{array}$} & $\begin{array}{c}\text { Ступінь тяжкості } \\
\text { НДСТ }\end{array}$ & $\begin{array}{c}\text { оксипролін вільний } \\
\text { (мкмоль/л) }\end{array}$ & $\begin{array}{c}\text { глікозаміноглікани } \\
\text { (мкмоль/л у сечі) }\end{array}$ & $\begin{array}{c}\text { кріоглобулін } \\
\text { (ум. од.) }\end{array}$ \\
\hline \multirow{2}{*}{$\begin{array}{c}\text { Основна } \\
(\mathrm{n}=106)\end{array}$} & легкий, $\mathrm{n}=34$ & $54,3 \pm 1,1$ & $70,43 \pm 1,1$ & $118,1 \pm 1,3$ \\
\cline { 2 - 5 } & середній, $\mathrm{n}=47$ & $69,7 \pm 1,8$ & $86,14 \pm 2,1$ & $234,8 \pm 2,5$ \\
\cline { 2 - 5 } & важкий, $\mathrm{n}=2$ & $92,5 \pm 1,4$ & $101,9 \pm 1,3$ & $312,3 \pm 2,4$ \\
\cline { 2 - 5 } & ізольована ПОВГ, $\mathrm{n}=23$ & $12,5 \pm 0,8$ & $41,3 \pm 1,1$ & $48,8 \pm 1,5$ \\
\hline \multicolumn{3}{|c|}{ Вірогідність достовірна $\mathrm{p}<0,05$} \\
\hline \multicolumn{3}{|c|}{ Контрольна група, $(\mathrm{n}=20)$} & $39,25 \pm 0,9$ & $40,3 \pm 1,2$ \\
\hline
\end{tabular}


глобуліну становили $(40,3 \pm 1,2)$ ум. од., при середньому ступені тяжкості НДСТ $(234,8 \pm 2,5)$ ум. од., а при тяжкому $(312,3 \pm 2,4)$ ум. од., що практично в шість разів перевищує норму.

Таким чином, показники вільного оксипроліну, кріоглобуліну та глікозаміноглікану чітко відображають ступінь тяжкості метаболічних порушень сполучної тканини і можуть слугувати діагностичним критерієм визначення дегенеративних змін сполучнотканинних структур передньої черевної стінки у хворих на післяопераційну вентральну грижу.

Згідно 3 результатами гістологічних досліджень ділянки білої лінії живота поряд з грижовим випинанням у пацієнтів із наявною неспецифічною дисплазією сполучної тканини виявлено, що колагенові та еластичні волокна стоншені, представлені дрібнопетлястою мережею, йдуть в різних напрямках і в різних площинах. Спостерігається розгалуження волокон, окремі фібрили повністю втрачають зв'язок з основними волокнами (рис. 1).

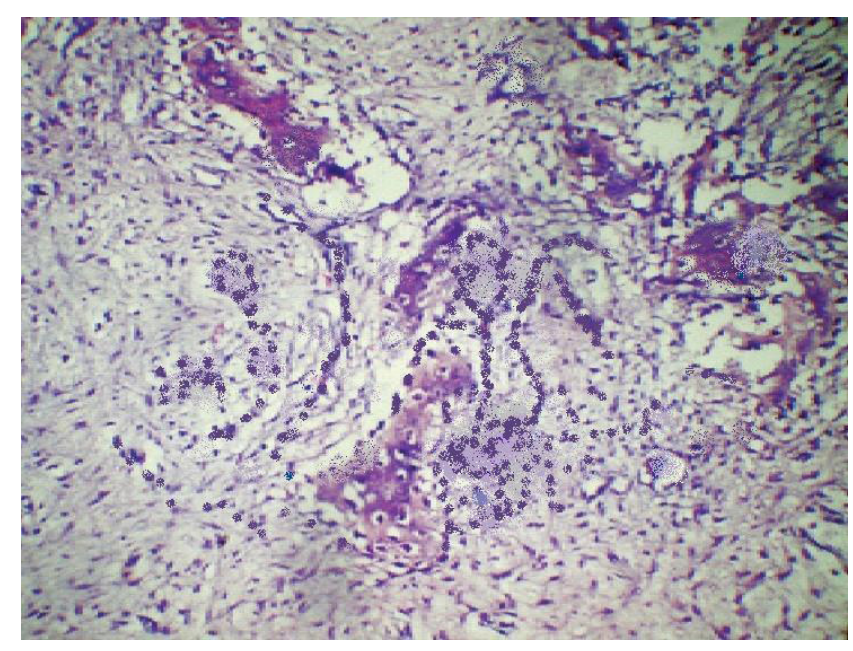

Рис. 1. Біла лінія живота поряд з грижовим випинанням і НДСТ. Забарвлення-тирозур. Збільшення × 100.

Згідно 3 результатами гістологічного дослідження ділянки м'язового волокна із фрагментом тяжкої поліпропіленової сітки Омега-4 виявлено помірну лімфогістіоцитарну інфільтрацію навколо волокон, яка поєднувалась із вираженим набряком строми, розволокненням колагенових волокон, помірним мукоїдним набряком. Спостерігалась незначна судинна реакція у вигляді повнокрів’я капілярів поєднана із периваскулярною клітинною інфільтрацією. Набряк поширювався на м'язову тканину, супроводжувався запальною інфільтрацією, деструкцією волокон та геморагічним просяканням тканини (рис. 2).

Гістологічне дослідження ділянки м'язового волокна із фрагментом легкої крупнопористої по-

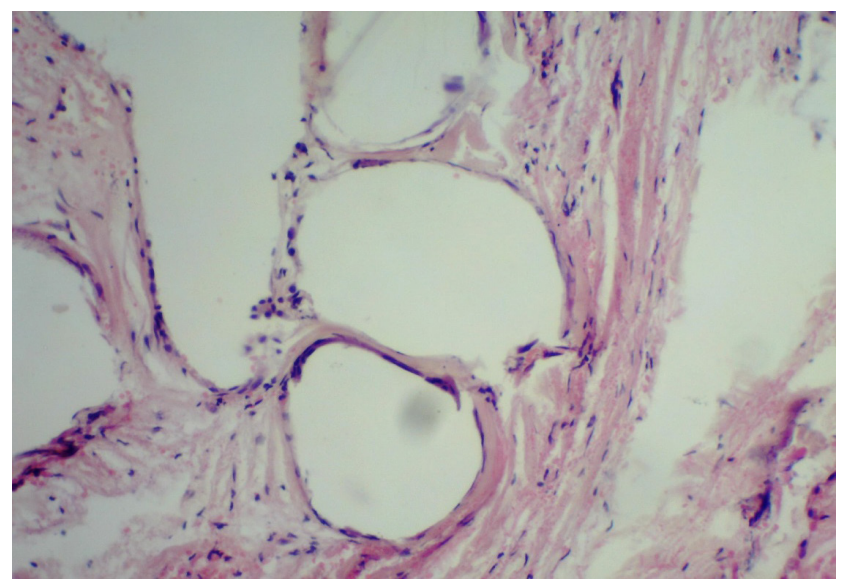

Рис. 2. Ділянка м'язового волокна із фрагментом поліпропіленової сітки Омега-4. Деструкція волокон та геморагічне просякання тканини. Забарвлення гематоксиліном та еозином. Збільшення $\times 100$.

ліпропіленової сітки Омега-2 виявило формування пухкої грануляційної тканини навколо волокон, основним компонентом якої були сформовані судини мікроциркуляторного русла, помірна кількість фібробластів, поодинокі колагенові волокна, інфільтровані лімфо- та гістіоцитами. Периваскулярний набряк не спостерігався. Грануляції щільно прилягали до м'язової тканини (рис. 3).

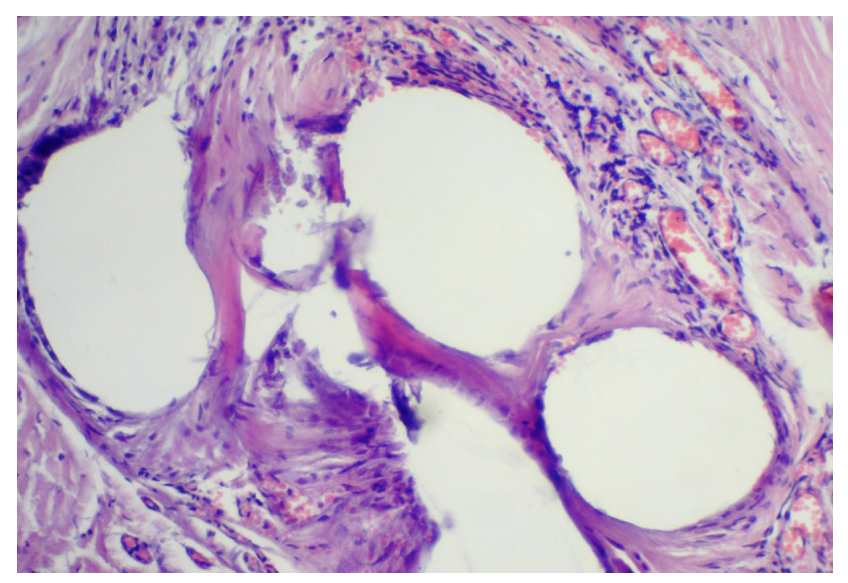

Рис. 3. Ділянка м'язового волокна із фрагментом поліпропіленової сітки Омега-2. Формування пухкої грануляційної тканини, яка щільно прилягає до м'язової. Забарвлення гематоксиліном та еозином. Збільшення $\times 100$.

Висновки. Таким чином проведення операційних втручань у хворих із наявною неспецифічною дисплазією сполучної тканини без урахування основних фенотипічних ознак та лабораторних досліджень колагеноутворювальної функції сполучної тканини з приводу як первинних, так і рубцевих гриж живота традиційними методиками $€$ малорезультативним і призводить до значної кількості рецидивувань. 
За наявності у пацієнтів 6 і більше фенотипічних ознак неспецифічної дисплазії сполучної тканини з клінічним підтвердженням порушення метаболізму сполучної тканини, що підтверджено значущим підвищенням вмісту вільного оксипроліну та кріоглобуліну в 3-4 рази, виконання лише герніопластик з використанням сітчастих імпланів методом sub lay.

\section{СПИСОК ЛІТЕРАТУРИ}

1. Білянський Л. С. Хірургічна тактика у хворих з гігантськими дефектами черевної стінки / Л. С. Білянський, I. М. Тодуров, С. В. Косюхно // Український журнал хірургії. - 2011. - № 2 (11). - С. 19-24.

2. Брек О. О. Морфометричні та гістологічні зміни тканин у хворих після операцій з приводу післяопераційних гриж черевної порожнини / О. О. Брек // Клінічна хірургія. - 2015. № 5. - С. 27-30.

3. Брек О. О. Стан сполучної тканини та його вплив на результати хірургічного лікування пацієнтів із післяопераційними вентральними грижами / О. О. Брек // Харківська хірургічна школа. - 2015. - № 1. - С. 31-35.

4. Дисплазія сполучної тканини, як предиктор виникнення гриж передньої черевної стінки : монографія / [За ред. В. П. Польового, В. В. Власова, В. В. Арсенюка]. - Чернівці : Медуніверситет, 2016. - 288 с.

5. Милиця К. М. Реконструктивно-відновлювальні операції на передній черевній стінці при синдромі недиференційованої дисплазії сполучної тканини : дис. ... канд. мед. наук : 14.01.01 / Милиця К. М. - Запоріжжя, 2009. - 258 с.

\section{REFERENCES}

1. Bilyanskyy, L.S., Todurov, I.M. \& Kosyukhno S.V. (2011). Khirurhichna taktyka u khvorykh z hihantskymy defektamy cherevnoi stinky [Surgical tactics in patients with giant abdominal wall defects]. Ukrayinskyi zhurnal khirurhii - Ukrainian Journal of Surgery, 2, (11), 19-24 [in Ukrainian].

2. Brek, O.O. (2015). Morfometrychni ta histolohichni zminy tkanyn u khvorykh pislia operatsiy z pryvodu pisliaoperatsiynykh hryzh cherevnoi porozhnyny [Morphometric and histological changes of tissues in patients after surgery for postoperative hernia of the abdominal cavity]. Klinichna khirurhiya-Clinical Surgery, 5, 27-30 [in Ukrainian].

3. Brek, O.O. (2015). Stan spoluchnoyi tkanyny ta yoho vplyv na rezultaty khirurhichnoho likuvannia patsiientiv iz pisliaoperatsiinymy ventralnymy hryzhamy [Condition of connective tissue and its influence on the results of surgical treatment of patients with postoperative ventral hernias]. Kharkivska khirurhichna shkola - Kharkiv Surgical School, 1, 31-35 [in Ukrainian].

4. Polovoho, V. P., Vlasova, V. V. \& Arsenyuka V. V. (Eds.) (2016). Dysplaziya spoluchnoi tkanyny, yak predyktor vynyknennia hryzh perednoi cherevnoyi stinky [Dysplasia of connective tissue as a predictor of the appearance of hernia of the anterior abdominal wall]. Monohrafiya. Chernivtsi: Meduniversytet, 288 [in Ukrainian].

5. Mylytsya, K. M. (2009). Rekonstruktyvno-vidnovlyuvalni ope-
Пріоритетним в плані застосування під час виконання герніопластики у пацієнтів на первинну вентральну та рубцеву грижу за умов наявної неспецифічної дисплазії сполучної тканини, не зважаючи на ступінь тяжкості останньої, є легкі крупнопористі сітки фірми «УКРТЕХМЕД» - Омега-2 стандарт, що підтверджується отриманими даними морфологічних досліджень.

6. Петров Д. Ю. Дифференцированный подход к выбору метода аллогерниопластики / Д. Ю. Петров, А. И. Ковалев, А. В. Смирнов // Актуальные вопросы герниологии: мат. конф. - Москва, 2013. - С. 119-121.

7. Фелештинський Я. П. Сучасні способи хірургічного лікування після операційних гриж живота / Я. П. Фелештинський // Здоров’я Укр. - 2012. - С. 24-27.

8. Breuing K. Ventral Hernia Working Group. Incisional ventral hernias: Review of the literature and recommendations regarding the grading and technique of repair / K. Breuing, C. E. Butler, S. Ferzoco // Surgery. - 2010. - No 148. - P. 544-558.

9. Chevrel J. P. Classification of incisional hernias of the abdominal wall / J. P. Chevrel, A. M. Rath // - Hernia. - 2000. No 1. - P. 1-7.

10. Pauli E. M. Open ventral hernia repair with component separation / E. M. Pauli, M. J. Rosen // Surg. Clin. North. Am. - 2013. - No 93. - P. 1111-1133.

11. Pallati P. K. Short-termout comesof inguinal hernia repairinocto genarian sandnona genarians / P. K. Pallati, P. K. Gupta, S. Bichala // Hernia. - 2013. - Vol. 17 (6). - P. 723-727.

ratsii na perednii cherevnii stintsi pry syndromi nedyferentsiovanoi dysplazii spoluchnoi tkanyny [Reconstructive-recovery operations on the front abdominal wall with syndrome of undifferentiated connective tissue dysplasia]. Extended abstract of candidate's thesis. Zaporizhzhia, 258.

6. Petrov, D.Yu., Kovalev, A.Y. \& Smyrnov A.V. (2013). Dyfferentsyrovannyy podkhod k vyboru metoda allohernyoplastyky [A differentiated approach to the choice of method Allogernioplasty]. Aktualnye voprosy hernyolohyy - Actual questions of herniology. Mat. konf. Moscow, 119-121 [in Russian].

7. Feleshtynskyy Ya.P. (2012). Suchasni sposoby khirurhichnoho likuvannia pisliaoperatsiynykh hryzh zhyvota [Modern methods of surgical treatment following surgical abdominal hernia]. Zdorovia Ukr. - Health Uk., 24-27 [in Ukrainian].

8. Breuing, K., Butler, C. E. \& Ferzoco, S. (2000). Ventral Hernia Working Group. Incisional ventral hernias: Review of the literature and recommendations regarding the grading and technique of repair. Surgery, 148, 544-558.

9. Chevrel J. P. \& Rath A. M. (2000). Classification of incisional hernias of the abdominal wall. Hernia, 1, 1-7.

10. Pauli, E. M. \& Rosen, M. J. (2013). Open ventral hernia repair with component separation. Surg. Clin. North. Am., 93, 1111-1133. 11. Pallati, P. K., Gupta, P. K. \& Bichala, S. (2013). Short-termout comesof inguinal hernia repairinocto genarian sandnona genarians. Hernia. 6, (17), 723-727. 


\title{
V.I. PIATNOCHKA
}

I. Horbachevsky Ternopil State Medical University

\section{DETERMINATION OF SPECIFIC SYMPTOMS OF NON-DIFFERENTIATED DISPLASIA OF CONNECTING TISSUE IN PATIENTS WITH POSTOPERATIVE VENTRAL HERNIA WITH THE SUBSTANTIATION OF THE VIBOR OF THE OPTIMUM METHOD OF OPERATIONAL INTERVENTION AND PROSTHETIC TYPE}

\begin{abstract}
The aim of the work: to develop tactical prerequisites and improve the results of surgical treatment of patients with postoperative ventral hernia based on the determination of clinical signs of undifferentiated connective tissue dysplasia with the subsequent choice of a pathogenetically substantiated method of surgical intervention and choice of alogransplant.

Materials and Methods. The results of surgical treatment of 106 patients operated on postoperative ventral hernia with implantation of lungs and heavy polypropylene mesh under conditions of existing connective tissue dysplasia were analyzed. The phenotypic signs of connective tissue dysplasia were studied according to the international scale M. J. Glesby (1994). To assess the state of metabolism, the content of hydroxyproline in the blood serum was studied. Normative values of biochemical parameters were obtained by examining 20 practically healthy persons (control), which were compared by age and sex with the examined 106 patients for postoperative ventral hernia. The content of blood serum cryoglobulins was determined by the method of N.A. Konstantinova and A.Yu. Kirsanov (1989). For morphological investigation for the purpose of determining nonspecific connective tissue dysplasia, during operative intervention, fragments of the aponeurosis of the white abdominal line near the hernia were taken. In 5 patients who re-operated with another pathology of the abdominal organs, with their consent, guided by the norms of medical bioethics, fragments of the anterior abdominal wall with an implanted heavy and easy mesh were taken for further morphological study. Results and Discussion. Dynamics of growth of the collagenolytic activity of the level of glycosaminoglycans and free hydroxyproline showed a direct correlation with the severity of nonspecific connective tissue dysplasia. Thus, for a mild degree, the serum hydroxyproline level was $(54.3 \pm 1.1) \mu \mathrm{mol} / \mathrm{l}$, the average degree $(69.7 \pm 1.8) \mu \mathrm{mol} / \mathrm{l}$. And a severe degree $(92.5 \pm 1.4) \mu \mathrm{mol} / \mathrm{l}$, which is almost 8 times higher than the norm. The corresponding dynamics to growth, depending on the degree of nonspecific connective tissue dysplasia, was also observed in the determination of glycosaminoglycans and cryoglobulin. Thus, in patients of the control group and in patients with isolated hernia, glycosaminoglycan indices practically did not differ and amounted to (39.25 \pm 0.9$) \mu \mathrm{mol} / \mathrm{L}$ in urine and $(41.3 \pm 1.1) \mu \mathrm{mol} / \mathrm{l}$ in urine, respectively. In the group of patients with medium and severe form of connective tissue dysplasia, they increased 2-2.5 times (101.9 \pm 1.3$) \mathrm{umol} / \mathrm{l}$ in urine. A similar increase in cryoglobulin indices was observed in comparison groups with increasing severity of connective tissue dysplasia. So, in the norm the cryoglobulin indices were $(40.3 \pm 1.2) \mathrm{cu}$, at an average severity of NDST $(234.8 \pm 2.5) \mathrm{cu}$, and for a severe $(312.3 \pm 2.4)) \mathrm{Cu}$, which is almost six times higher than the norm. Morphological studies showed prioritites when using a light large-sized polypropylene omega-2 mesh that manifested itself in the absence of perivascular edema, the formation of loose granulation tissue around the fibers, a moderate amount of fibroblasts, and a large number of collagen fibers infiltrated by lympho- and histiocytes.
\end{abstract}

Key words: postoperative ventral hernia; relapse of undifferentiated connective tissue dysplasia (NDST); phenotypic signs of dysplasia; hydroxyproline; polypropylene mesh.

\section{В. И. ПЯТНОЧКА}

гВУз “Тернопольский государственный медицинский университет имени И. Я. Горбачевского”

\section{ОПРЕДЕЛЕНИЕ СПЕЦИФИЧЕСКИХ ПРИЗНАКОВ НЕДИФФЕРЕНЦИРОВАННОЙ ДИСПЛАЗИИ СОЕДИНИТЕЛЬНОЙ ТКАНИ У ПАЦИЕНТОВ С ПОС.ЛЕОПЕРАЦИОННОЙ ВЕНТРАЛЬНОЙ ГРЫЖЕЙ С ОБОСНОВАНИЕМ ВЫБОРА ОПТИМАЛЬНОГО СПОСОБА ОПЕРАТИВНОГО ВМЕНАТЕЛЬСТВА И ТИПА ПРОТЕЗА}

\footnotetext{
Цель работы: разработать тактические предпосылки и улучшить результаты хирургического лечения больных с послеоперационной вентральной грыжей на основе определения клинических признаков недифференцированной дисплазии соединительной ткани с последующим выбором патогенетически обоснованного способа оперативного вмешательства и выбора аллотрансплантанта.

Материалы и методы. Проанализированы результаты хирургического лечения 106 пациентов оперированных на послеоперационную вентральную грыжу с имплантацией легких и тяжелых полипропиленовых сеток в условиях имеющейся дисплазии соединительной ткани. Изучались фенотипические признаки дисплазии соединительной ткани по международной шкале M. J. Glesby (1994). Для оценки состояния метаболизма изучали содержание в сыворотке крови оксипролина. Нормативные значения биохимических показателей получены при обследовании 20 практически здоровых лиц (контроль), которые сопоставлены по возрасту и полу с обследованными 106 больными на послеоперационную вентральную грыжу. Содержание криоглобулинов сыворотки крови определяли по методике Н. А. Константиновой и А. Ю. Кирсанова (1989). Для морфологического исследования на предмет определения неспецифической дисплазии соединительной ткани во время оперативного вмешательства осуществляли забор фрагментов апоневроза белой линии живота рядом с грыжей. У 5 больных, которые повторно оперировались с другой патологией органов брюшной полости, при их согласии, руководствуясь нормами медицинской биоэтики, забирались фрагменты передней брюшной стенки с имплантированной тяжелой и легкой сеткой для дальнейшего морфологического изучения.
} 


\section{ОРИГІНАЛЬНІ ДОСЛІДЖЕННЯ}

Результаты исследований и их обсуждение. Динамика роста коллагенолитичесской активности уровня гликозаминогликанов и свободного оксипролина прослеживалась прямая корреляционная связь со степенью тяжести неспецифической дисплазии соединительной ткани. Так, при легкой степени уровень сывороточного оксипролина составил $(54,3 \pm 1,1)$ мкмоль/л, средней степени $(69,7 \pm 1,8)$ мкмоль/л и тяжелой степени $(92,5 \pm 1,4)$ мкмоль/л, что практически в 8 раз превышало показатели нормы. Соответствующая динамика к росту в зависимости от степени выраженности неспецифической дисплазии соединительной ткани наблюдали и при определении показателей гликозамингликанов и криоглобулина. Так, у пациентов конторольной группы и у пациентов с изолированной грыжей показатели гликозамингликанов практически не отличались и составляли $(39,25 \pm 0,9)$ мкмоль / л в моче и соответственно $(41,3 \pm 1,1)$ мкмоль/л в моче, однако в группе пациентов со средней и тяжелой формамий дисплазии соединительной ткани они увеличивались в $2-2,5$ раза $(101,9 \pm 1,3)$ мкмоль/л в моче. Аналогичный рост показателей криоглобулина отмечено в группах сравнения с ростом тяжести дисплазии соединительной ткани. Так, в норме показатели криоглобулина составляли $(40,3 \pm 1,2)$ у. е., при средней степени тяжести НДСТ $(234,8 \pm 2,5)$ у. е., а при тяжелой $(312,3 \pm 2,4)$ у. е., что практически в шесть раз превышает норму. Морфологические исследования показали приоритеты при использовании легкой крупноячеестой полипропиленовой сетки Омега-2, что проявлялось в отсутствии периваскулярного отека, формировании рыхлой грануляционной ткани вокруг волокон, умеренным количеством фибробластов, большим количеством коллагеновых волокон, инфильтрированных лимфо- и гистиоцитами.

Ключевые слова: послеоперационная вентральная грыжа; рецидив; недиференцированная дисплазия соединительной ткани (НДСТ); фенотипические признаки дисплазии; оксипролина; полипропиленовая сетка. 